\title{
The Evaluation of the Fertility in Stallions Used for Natural Breeding
}

\author{
Iancu MORAR ${ }^{1}$, Ioan Ştefan GROZA ${ }^{1}$, Melania Ioana CRIŞAN ${ }^{2 *}$ and Alexandra DREANCĂ ${ }^{1}$ \\ ${ }^{1}$ Department of Reproduction, Obstetrics and Veterinary Gynecology, Faculty of Veterinary Medicine, \\ University of Agricultural Sciences and Veterinary Medicine of Cluj-Napoca, Romania \\ ${ }^{2}$ Department of Comparative Anatomy, Faculty of Veterinary Medicine, University of Agricultural Sci- \\ ences and Veterinary Medicine of Cluj-Napoca, Romania \\ *Corresponding author, e-mail: melaniacrisan@gmail.com
}

Bulletin UASVM Veterinary Medicine 71(2) / 2014,

Print ISSN 1843-5270; Electronic ISSN 1843-5378

DOI:10.15835/buasvmcn-vm: 10835

\begin{abstract}
The success of horse breeding is depending on the fertility of the stallions and on the fertility of the mares. It is important to assess the clinical examination of a stallion and the quality of its semen in order to prevent the transmission of numerous diseases and to appreciate the fertility of the animal. The main purpose of this work was to establish a protocol for the evaluation of the fertility of the chosen stallions. We were interested in realizing a general clinical examination and of the genital apparatus, a detailed laboratory exam of the collected semen and the pregnancy rate in broodmares.

This study was conducted on eight adult stallions. After a general clinical exam, the semen was collected and evaluated macroscopically and microscopically by using the photometric method device Spermacue (Minitub). The fertility of each stallion was assessed by the pregnancy rate of the brood mares ( $\mathrm{n}=5$ for each animal).

All the examined stallions were clinically healthy. The average of the semen volume was $74 \mathrm{ml}$, the average concentration of spermatozoids was $120 \mathrm{million} / \mathrm{ml}$. The viability of the semen and the motility of the spermatozoids was $50 \%$. Only 3 stallions presented subfertility.

For the assessment of the fertility in stallions it is mandatory to realize a complete clinical examination and also to test the immunity of the animal. In the present research work, we demonstrated that the exam of the semen is the most important step for evaluating the fertility of the stallions.
\end{abstract}

Keywords: clinical exam, fertility, semen, stallion, subfertility.

\section{INTRODUCTION}

The importance of the horse nowadays resides mostly from the sportive activity of this animal. The breeding in this specie has a major economic impact. In Romania, natural breeding in equine is regularly used. The success of this method is depending on one hand by the fertility of the stallions and on the other hand by the fertility of the used mares. It is important to assess the clinical examination of a stallion and the quality of its semen in order to prevent the transmission of numerous diseases and to appreciate the fertility of the animal (Morar et al., 2004). Detailed clinical examinations followed by a laboratory exam of the semen are required for the improvement of the equine reproduction. The anamnesis, inspection and palpation are realized in order to evaluate the behavior of the stallion, its fertility and to assess the evaluation of the genital apparatus as well as the general body condition of the animal (Pycock, 2012).

As for the collection of the semen, the most popular technique is the one using the artificial vagina (Morar et al. 2004). No matter what method is used, specific criteria need to be respected: the recommended age of the donor stallion is minimum 3 years (Varner et al., 1992); the dressage of the stallion for this procedure should 
start once the sexual maturity is reached (Morar et al., 2004) and for the stallions with a psychological instability the chemical semen collection should be used (Samper, 2009). The nutrition is a key element in the development of the animal as well as the light and stable conditions.

The evaluation of the semen is the most important stage, because it offers us information if about the fertility of the stallion, the capacity of the semen to be preserved and used for artificial insemination afterwards. This exam is related both to the fertility of the male as well as to the dilution technique and the preservation process (Morar et al. 2004; Ball, 2008). In order to realize a complete exam of the semen, a macroscopic, microscopic, biochemical and bacteriological exam is needed. The volume of the semen is related to the age, breed and testicular development of the stallion (Soderquist, 1991) and varies between 30 to $250 \mathrm{ml}$ (Groza et al. 2006). The color of the semen is whitish, slightly grey and opaque. The color changes are related to different diseases: brownish in orchitis, reddish when the blood is present, yellowish when the sperm is mixed with urine and yellow-greenish with a inhomogeneous aspect in infections with Pseudomonas (Pycock, 2012).

The microscopical exam of the semen is focused on the concentration of spermatozoids which can be determined by using different methods: hematometry, photometric method and the electronic one. In stallion the average concentration is 100-300 x $10^{6}$ (Groza et al., 2006). The total quantity of spermatozoids varies between 0.6 and $48 \times 10^{9}$ with an average of $6 \times 10^{9}$ (Bogdan and Groza, 2009). The density of the semen in stallions is between 100 to 300 million spermatozoids per milliliter (Kenny, 1983; Morar et al. 2004). The mobility of the spermatozoids is one of the most important characteristic that needs to be evaluated, because its value is essential in the technological process of crioconservation of the semen. The average speed is $5.22 / \mathrm{mm}$ and the percentage of the spermatozoids in the microscopic field should be $80 \%$ to $90 \%$ (Morar et al., 2004).The ejaculates that presents a mobility lower than $50 \%$ before freezing are eliminated. Nowadays in the reproduction centers exists a modern system (CASA) that analyses in the same time the concentration of spermatozoids and their mobility (Samper, 2009). The metabolism and the morphology of the spermatozoids are two other criteria that need to be evaluated.

\section{MATERIALS AND METHODS}

The main objectives of this work were realize a clinical evaluation of the stallions, of their genital apparatus, to collect the semen and to evaluate it both macroscopically and microscopically and in the end to evaluate the fertility of the stallions according to the pregnancy rate in brood mares.

The study was conducted on eight adult stallions of different age and breed in the breeding season of 2014 coming from Cluj County. The semen collection and its evaluation were realized on the field, by respecting all the safety measurements. The first step consisted in taking the anamnesis for each stallion: age, sexual activity, diseases that could interfere with the quality of the semen and the pregnancy rate of the brood mares. Also, a general clinical exam, focused mostly on the genital apparatus was performed for each animal.

The collection of the semen was realized by using the artificial vagina CSU, which major advantage is to maintain the temperature of the water in normal limits $\left(40^{\circ} \mathrm{C}\right.$ to $\left.42^{\circ} \mathrm{C}\right)$ more than other models (Morar et al., 2004). A lubricant non spermicide gel was used at its end and the mare was prepared as for breeding. The breeding reflexes were analyzed for each stallion and an andrologic profile was created for each animal.

The collected semen was evaluated immediately and we were interested in analyzing the volume, smell, color as well as the concentration, viability, density and motility.

For the concentration we used using the photometric method device Spermacue (Minitub). The viability, density and motility were evaluated by using the microscope. The fertility of each stallion was assessed by the pregnancy rate of the brood mares ( $\mathrm{n}=5$ for each animal).

\section{RESULTS AND DISCUSSION}

All the stallions were evaluated by using a general clinical examination. They belong to Polish draft horse $(n=3)$, Romanian draft horse $n(=2)$, Frisian $(n=1)$ and Lipizzaner breed $(n=1)$, aged between 4 and 11 years and with a good body condition and body score. The sexual reflexes varied from moderate $(n=2)$ to increased $(n=4)$. All the results are noted in Tab. 1. 
Tab. 1 The general information about the stallions

\begin{tabular}{|c|c|c|c|c|c|c|c|c|}
\hline Nr. Crt. & $\begin{array}{c}\text { Stallion } \\
1\end{array}$ & $\begin{array}{c}\text { Stallion } \\
2\end{array}$ & $\begin{array}{c}\text { Stallion } \\
3\end{array}$ & $\begin{array}{c}\text { Stallion } \\
4\end{array}$ & $\begin{array}{c}\text { Stallion } \\
5\end{array}$ & $\begin{array}{c}\text { Stallion } \\
6\end{array}$ & $\begin{array}{c}\text { Stallion } \\
7\end{array}$ & $\begin{array}{l}\text { Stallion } \\
8\end{array}$ \\
\hline Breed & $\begin{array}{l}\text { Polish } \\
\text { draft } \\
\text { horse }\end{array}$ & $\begin{array}{l}\text { Polish } \\
\text { draft } \\
\text { horse }\end{array}$ & $\begin{array}{l}\text { Polish draft } \\
\text { horse }\end{array}$ & Frisian & $\begin{array}{l}\text { Romanian } \\
\text { draft horse }\end{array}$ & $\begin{array}{l}\text { Romanian } \\
\text { draft horse }\end{array}$ & Lipizzaner & $\begin{array}{l}\text { Romanian } \\
\text { draft horse }\end{array}$ \\
\hline Age (years) & 4 & 4 & 4 & 6 & 9 & 11 & 9 & 11 \\
\hline Constitution & Robust & Robust & Robust & Light & Robust & Robust & Light & Robust \\
\hline Conformation & Good & Good & Good & Good & Good & Good & Good & Good \\
\hline Body score & Good & Good & Good & Good & Good & Good & Good & Good \\
\hline Temperament & Active & Active & Active & Active & Active & Active & Active & Active \\
\hline Clinical exam & Normal & Normal & Normal & Normal & Normal & Normal & Normal & Normal \\
\hline $\begin{array}{c}\text { Sexual } \\
\text { reflexes }\end{array}$ & Normal & Increased & Moderate & Increased & Moderate & Increased & Increased & Increased \\
\hline $\begin{array}{l}\text { \% Fertility } \\
\text { (Pregnancy } \\
\text { rate) }\end{array}$ & $80 \%$ & $90 \%$ & Subfertility & $100 \%$ & Subfertility & Subfertility & $80 \%$ & $80 \%$ \\
\hline
\end{tabular}

After it was collected by using the artificial vagina CSU, the semen was evaluated both macroscopically and microscopically. The average volume of the semen was 74 mililiters ( $\mathrm{ml})$, varying from 30 to $250 \mathrm{ml}$, but for the stallion who had 250 $\mathrm{ml}$ of ejaculate (Stallion 6), only $50 \mathrm{ml}$ represented the spermatic part. We have noticed in this study that the volume of the semen is not related to the fertility of the stallion. The color and the smell of the sperm were normal in all stallions except for one, in which it was transparent white and it presented a specific smell (Tab. 2). The average concentration of the sperm was 120 million per $\mathrm{ml}$, varying in between 80 to 147 million (Tab. 2). It was noticed that stallions with concentrations over 100 million of spermatozoids per $\mathrm{ml}$ had better results and influences in a positive way the viability and mobility of spermatozoids. The viability is around $50 \%$ ranking from $20 \%$ to $80 \%$ (Tab. 2). This is one of the most important parameters that influences in a positive way the fertility and it is the parameter that can determine if the collected semen can be used for artificial insemination raw or frozen. The mobility of the spermatozoids had

Tab. 2. The macroscopic and microscopic characteristics of collected semen

\begin{tabular}{ccccccccc}
\hline $\begin{array}{c}\text { Macrosopic } \\
\text { exam }\end{array}$ & $\begin{array}{c}\text { Stallion } \\
1\end{array}$ & $\begin{array}{c}\text { Stallion } \\
2\end{array}$ & $\begin{array}{c}\text { Stallion } \\
3\end{array}$ & $\begin{array}{c}\text { Stallion } \\
4\end{array}$ & $\begin{array}{c}\text { Stallion } \\
5\end{array}$ & $\begin{array}{c}\text { Stallion } \\
6\end{array}$ & $\begin{array}{c}\text { Stallion } \\
7\end{array}$ & $\begin{array}{c}\text { Stallion } \\
8\end{array}$ \\
\hline $\begin{array}{c}\text { Volume } \\
\text { (ml) }\end{array}$ & 60 & 70 & 30 & 40 & 30 & 50 & 50 & 60 \\
\hline Color & Normal & Normal & Normal & Normal & Normal & $\begin{array}{c}\text { Transparent } \\
\text { white }\end{array}$ & Normal & Normal \\
\hline Smell & Normal & Normal & Normal & Normal & Normal & Normal & Normal & Normal \\
\hline $\begin{array}{c}\text { Microsopic } \\
\text { exam }\end{array}$ & $\begin{array}{c}\text { Stallion } \\
1\end{array}$ & $\begin{array}{c}\text { Stallion } \\
2\end{array}$ & $\begin{array}{c}\text { Stallion } \\
3\end{array}$ & $\begin{array}{c}\text { Stallion } \\
4\end{array}$ & $\begin{array}{c}\text { Stallion } \\
5\end{array}$ & $\begin{array}{c}\text { Stallion } \\
6\end{array}$ & $\begin{array}{c}\text { Stallion } \\
7\end{array}$ & $\begin{array}{c}\text { Stallion } \\
8\end{array}$ \\
\hline Mobility & $60 \%$ & $70 \%$ & $20 \%$ & $80 \%$ & $20 \%$ & $30 \%$ & $70 \%$ & $80 \%$ \\
\hline $\begin{array}{c}\text { Concentration } \\
\text { (million) }\end{array}$ & 142 & 147 & 99 & 145 & 80 & 89 & 117 & 103 \\
\hline $\begin{array}{c}\text { Total number } \\
\text { (million) }\end{array}$ & 8520 & 10290 & 2970 & 5800 & 2400 & 4450 & 5850 & 6180 \\
\hline
\end{tabular}


the same values as the viability, reason for each we can sustain that there is a direct connection between the viability of the spermatozoids and their mobility. Some authors claim that the most important parameter of the semen is the mobility of the spermatozoids. Their studies show that 75\% out of 20 mares inseminated with a small volume of semen with a moderate viability but with a high mobility presented a pregnancy rate (Varner et al. 1992).

The fertility of each stallion was assessed by the pregnancy rate of the brood mares ( $n=5$ for each animal). All the mares were evaluated clinically and by ultrasound exam to determine the optimum moment for breeding. Each mare was bred multiple times during one cycle. The evaluation of the pregnancy rate was done by ultrasound exam after the last breeding (Tab. 1).

Out of the total of eight stallions, three were found to present subfertility due to the low volume of semen (30 ml), a low concentration of spermatozoids and a low mobility and viability of them (20\%). The stallion number 3, 5 and 6 presented oligospermia. The low quality of the semen in these cases can be related to: pyrexia, overstressing, nutrition, or the use of different drugs like corticosteroids (Pycock, 2012). In our set of animals, one presented pyrexia and we suppose that the subfertility was connected to that. In another study (Varner, 2011), the authors claim that the fertility is directly influenced by the type of mares used for breeding. The one with foals obtained by natural breeding had a higher pregnancy rate compared to the young ones or the adults without foal.

\section{CONCLUSIONS}

1. According to our results, it is mandatory to realize a complete clinical and immunological exam of the stallions before the breeding season. All the cases included in the study were clinically healthy.

2. The collecting of the semen by using artificial vagina CSU proved to be very efficient.

3. The evaluation of the semen is the most important step in establishing the fertility of the sta+llions.
4. The average volume of the semen was 74 milliliters (ml). The average concentration of the sperm was 120 million per $\mathrm{ml}$, varying in between 80 to 147 million.

5 . The viability and mobility of spermatozoids was around $50 \%$ ranking from $20 \%$ to $80 \%$.

6 . The pregnancy rate has a major influence on the fertility of the stallions. In our series, five stallions were fertile and three presented subfertility.

7. The evaluation of stallions used for breeding needs to be done yearly, before each breeding season in order to establish the number of mares that can be bred by it, the frequency of breeding and the fertility of the stallions.

Acknowledgements: This paper was published under the frame of European Social Fund, Human Resources Development Operational Program 20072013, project no. POSDRU/159/1.5/S/136893.

\section{REFERENCES}

1. Ball BA (2008). Diagnostic methods for evaluation of stallion subfertility: a review. Journal of Equine Veterinary Science 28(11): 650-665.

2. Bogdan L, Groza IS (2009). Obstretica Veterinară, editura Academic Pres: 3-25;

3. Groza, IŞ, Bogdan L, Cătană R, Cenariu M, Ciupe S, Ciupercescu DD, Morar I, Muntean M, Pop RA, Stegeran B. (2006). Ginecologie, andrologie şi obstetrică veterinară, Ed. Academiei Române, București: 63-65, 75-90, 115-117, 138-140, 204-211.

4. Kenny RM (1983). Manual for Clinical Fertility Evaluation of the Stallion, Hastings, , NE, Society for Theriogenology: 3-100.

5. Morar I, Groza IS (2004). Manual practic de însămânţări artificiale la cabaline, Proiect biotech: 4-59.

6. Pycock JF (2012). Stallion and Semen evaluation. Proceedings of the 51 th British Veterinary Congress (www.ivis.org).

7. Samper JC (2009). Equine breeding,management and artificial insemination, Sauders: 33-170.

8. Söderquist L, Janson L, Larsson K, Einarsson S (1991). Sperm morphology and fertility in A.I. bulls. J Vet Med 38:534-543.

9. Varner D, Blanchard T (1992). Stallion management. Vet Clin North Am Equine Pract 8: 219-235. 